\title{
THE TREATMENT OF EARLY SYPHILIS BY INTENSIVE AND SEMI-INTENSIVE ARSENOTHERAPY
}

\author{
By W. V. MACFARLANE, M.D., D.P.H. \\ Clinical Medical Officer, Joint Committee's Clinic, Newcastle upon Tyne
}

In the treatment of early syphilis, recent years have witnessed changes not only in the arsenical preparations employed but-which is equally important-in the length of the actual treatment period. The exigencies of wartime with the consequent need for the conservation of man-power, together with the ever-shifting population demanded by industry, have given an impetus to the study of short-term intensive treatment.

Efforts have been made to curtail the time phase over which treatment is spread, because the defaulter rate varies directly with the length of the treatment period. The arsphenamines and neoarsphenamines are being replaced, for the time being, by various arsenoxide preparations, namely, Mapharsen in the United States of America and Mapharside and Neohalarsine (arsphenoxide tartrate) in Great Britain.

The various forms of intensive therapy applicable to early syphilis are at present sufficiently numerous to warrant the conclusion that this therapeutic approach to early syphilis is still in the experimental phase. There are, for example, treatment with Mapharsen and fever therapy (Jones and his colleagues; Thomas and Wexler); the administration of Mapharsen by the intravenous-drip method over a period of a few days (Co-operating Clinics of New York, etc.); the 10-day syringe method of treatment (Schoch and Alexander ${ }^{2}$ ); the 20-day (Schoch and Alexander ${ }^{1}$ ) or 30-day (Goldblatt) treatment in which consecutive daily injections of Mapharsen are given; thrice-weekly injections of Mapharsen (with or without bismuth) over a period ranging from 7 to 12 or from 9 to 12 weeks (Eagle); and the 16 weeks' (Schaffer and Salchow) treatment schedule and the 26 weeks' course of concurrent Mapharsen and bismuth adopted by the Army of the United States. These schemes provide an array of treatment schedules from which a standard treatment may emerge in the course of time. This forecast assumes, however, that penicillin may not fulfil its early promise of being the most valuable antisyphilitic therapeutic agent yet discovered. The possibility of combined arseno-penicillin therapy cannot be ignored.

It will be noted that the degree of intensity in treatment varies considerably in the different schedules mentioned above. With a view to formulating a broad classification, the term, hyper-intensive, may be applied when treatment is condensed into a few days, say 10 at the most ; the term, intensive, could be applied to those therapeutic measures administered over a period of $20-30$ days; perhaps the expression, semi-intensive, would best describe the relatively leisurely treatment given over a period of 7-12 weeks.

Our series of 120 cases therefore falls into the latter categories, approximately 72 per cent coming within the intensive group. The hyper-intensive systems were avoided deliberately, because apparently good results are often achieved at the expense of an admittedly big percentage of complications and a relatively high mortality rate.

\section{Types of treatment used}

The 20-day or 30-day intensive courses comprised 20 or 30 consecutive daily injections of Neohalarsine, 0.09 gramme, or of Mapharside, 0.06 gramme, respectively. The semi-intensive treatment consisted of a 7 weeks' course of Neohalarsine or of Mapharside, injections being given thrice weekly in similar dosage.

Intensive treatment was carried out only for in-patients, whereas semi-intensive treatment was applied mainly to out-patients. Bismuth (an insoluble compound preparation), 2 injections of 0.2 gramme weekly, was given during all three types of treatment (20-day, 30-day and 49-day). The use of semi-intensive therapy was 
restricted to young adults otherwise in good health, and the 7 weeks' course of treatment to adults not exceeding 45 years of age.

The series of 120 cases comprised 60 male and 14 female patients, all of British nationality and resident on Tyneside ; the remaining 46 were merchant seamen (14 British, 12 Danish, and 10 from various countries including Esthonia, Canada, Sweden, Finland and Uruguay). The distribution of the cases according to the stage of the disease and the intensity of treatment is shown in Table 1.

TABLE 1-STAGE OF DISEASE AND TYPE OF TREATMENT EMPLOYED

\begin{tabular}{|c|c|c|c|c|c|c|c|c|}
\hline \multirow{2}{*}{\multicolumn{5}{|c|}{$\begin{array}{c}\text { Classification according to type } \\
\text { of syphilis }\end{array}$}} & \multicolumn{4}{|c|}{. Classification according to type of treatment } \\
\hline & & & & & \multirow{2}{*}{ 20-day } & \multicolumn{2}{|l|}{ 30-day } & \multirow{2}{*}{ 49-day } \\
\hline Seronegative Primary & $\cdots$ & . & . & $\cdots$ & & 3 & . & \\
\hline Seropositive Primary & $\cdots$ & $\cdots$ & . & $\cdots$ & 26 & 1 & " & 8 \\
\hline Sero-doubtful Primary & $\cdots$ & $\cdots$ & $\cdots$ & $\cdots$ & 3 & 一 & & 4 \\
\hline Secondary & . & . & $\cdots$ & $\cdots$ & 24 & 15 & & 7 \\
\hline Latent $\quad \ldots \quad \ldots$ & $\cdots$ & - & . & $\cdots$ & 1 & 一 & & - \\
\hline Total number of cases & $\cdots$ & . & . & . & 73 & - 19 & & 28 : $28 r^{*}$ \\
\hline Distribution according & to sex & $\cdots$ & $\cdots$ & -. & $\begin{array}{l}8 \text { females } \\
65 \text { males }\end{array}$ & $\begin{array}{l}3 \text { females } \\
16 \text { males }\end{array}$ & & $\begin{array}{l}3 \text { females } \\
25 \text { males }\end{array}$ \\
\hline
\end{tabular}

\section{Results of treatment}

The serological results of treatment of the three various types and those recorded in the follow-up of the cases in the various groups are shown in Tables 2 and 3. The conversion rate of the Wassermann reaction is given in Table 4.

Normal findings in the cerebrospinal fluid examination were present in 28 patients who were subjected to this test during the follow-up period. Generally speaking, cerebrospinal fluid examination was performed 6 months after cessation of treatment, but in a few cases repeated examinations were made over a period of 12-16 months.

To date, 2 patients have relapsed, after 5 and 3 months' surveillance : in the former case the relapse was both clinical and serological in a patient with secondary syphilis; the latter case, a patient with seropositive primary syphilis, showed only serological relapse. Both patients responded to a further course of arsenic and bismuth, given concurrently at weekly intervals for a period of 10 weeks.

The total number of intravenous injections given was 2,618 , covering the various courses of treatment in the 120 cases. It is interesting to note that one patient, aged 21 years, who was in the eighth month of pregnancy, tolerated 30 consecutive daily injections of Neohalarsine (each of 0.06 gramme) with bismuth bi-weekly and remained perfectly well during and subsequent to treatment.

\section{Complications}

The incidence of complications is shown in Table 5.

Pyrexial reactions. - In the 20-day treatment group 5 patients had pyrexial reactions, 3 of which consisted of primary fever occurring within the first 48 hours of treatment and were of a transient nature. One case of secondary fever was so severe-temperature $104^{\circ} \mathrm{F}$., sickness and vomiting-that intensive therapy had to be discontinued.

Dermatitis.-Only 3 cases of arsenical dermatitis were observed, one occurring during 30-day treatment. This patient showed a widespread morbilliform rash of 2-3 days' duration, which occurred on the twenty-eighth day of treatment: 
Probably arsenical sensitivity rather than toxicity was the causal factor, since the patient had a perivascular infiltration 24 hours before the eruption commenced.

In the 49-day series, 2 cases of dermatitis were recorded. A transient erythematous rash was noticed in one, but the second case was of a more seriaus type. In a girl, 14 years of age, suffering from secondary syphilis, a papular type of rash, mainly restricted to the extremities, developed on the day after the completion of her course of treatment. Intravenous calcium thiosulphate injections and local applications gave considerable relief, and recovery was complete after one month.

TABLE 2-IMMEDIATE EFFECTS OF TREATMENT ON THE WASSERMANN REACTION

\begin{tabular}{|c|c|c|c|c|c|c|c|}
\hline \multirow{3}{*}{$\begin{array}{l}\text { TYPE OF } \\
\text { TREATMENT }\end{array}$} & \multirow{3}{*}{$\begin{array}{l}\text { TOTAL } \\
\text { NUMBER } \\
\text { OF CASES }\end{array}$} & \multicolumn{6}{|c|}{ BEHAVIOUR OF WASSERMANN REACTION } \\
\hline & & \multicolumn{3}{|c|}{$\begin{array}{l}\text { Between } 7 \text { th and } 11 \text { th } \\
\text { day of treatment }\end{array}$} & \multicolumn{3}{|c|}{$\begin{array}{l}\text { Immediately on cessation } \\
\text { of treatment }\end{array}$} \\
\hline & & Positive & Negative & Doubtful & Positive & Negative & Doubtful \\
\hline
\end{tabular}

\begin{tabular}{rrrr|r|r|r|r|r|r|r|r}
\multicolumn{1}{c}{ Seronegative Primary Syphilis } \\
\hline 20-day &.. &.. &.. & 19 & 4 & 11 & 4 & - & 18 & 1 \\
30-day &.. &.. &.. & 3 & 1 & 2 & $\cdot-$ & 1 & 2 & - \\
$49-$ day &.. &.. &.. & 9 & - & 9 & - & - & 9 & - \\
\hline
\end{tabular}

\begin{tabular}{rrrr|r|r|r|r|r|r|r|r}
\multicolumn{10}{c}{ Seropositive Primary Syphilis } \\
\hline 20-day &.. &., &.. & 26 & 23 & 1 & 2 & 15 & 8 & 3 \\
49-day &.. &.. &.. & 8 & 8 & - & - & 2 & 6 & - \\
\hline
\end{tabular}

\begin{tabular}{cccc|c|c|c|c|c|c|r|r}
\hline \multicolumn{1}{c}{ Sero-doubtful Primary Syphilis } \\
\hline 20-day &.. &.. &.. & 3 & - & 3 & - & 2 & 1 & - \\
49-day &.. &.. &.. & 4 & 2 & 1 & 1 & - & 3 & 1 \\
\hline
\end{tabular}

\begin{tabular}{cccc|c|c|c|c|c|c|c|c}
\hline 10 & \multicolumn{1}{c}{ Secondary Syphilis } \\
\hline 20-day &.. &.. &.. & 24 & 24 & - & - & 18 & 4 & 2 \\
30-day &.. &.. &. & 15 & 15 & - & - & 10 & 1 & 4 \\
$49-$ day &.. &.. &.. & $7 *$ & 6 & 1 & - & 2 & 3 & - \\
\hline
\end{tabular}

* Two patients defaulted during treatment and their records are therefore omitted from the series.

Jaundice.-In 3 patients jaundice developed 7-21 days after completion of the 49-day form of therapy. Two cases were mild, clearing in 10-28 days, but the condition persisted in the third patient for 10 weeks. Jaundice was not prevalent in the out-patient clinic at that time, and all syringes, needles and other instruments were sterilized before use on each and every occasion.

Incidence of complications.-The great majority of the complications occurred in patients resident in the district ; in only 2 cases did they occur in patients from the Merchant Navy. The incidence of complications was higher in males, but this statement is of relative value, since only 14 females were treated by the above methods. As to the relative merits in this respect of the two preparations of arsenoxide employed in all three series, there was nothing to choose between Neohalarsine and Mapharside.

Whereas the incidence of complications was numerically about equal in the 7 weeks' course of treatment as compared with the 20-day type, the complications which occurred in the former group were of a more serious nature. Such factors as adequate or inadequate control over the conditions of life during treatment- 
including diet (especially the lack of vitamins and of first-class proteins), alcohol intake, rest and avoidance of chills-in all probability played an important part, especially in cases treated as out-patients.

Tolerance of intensive treatment.-The tolerance of treatment shown by those patients who were subjected to the 20-day and 30-day types of therapy indicates that the majority of patients, if in other respects enjoying normal health, tolerate this type of treatment remarkably well.

Goldblatt employed the 30-day treatment (using arsenic alone) for 107 patients (most of whom attended as out-patients); he concluded that, since toxic effects were mild, such a form of therapy could be employed in the out-patient department, always provided that a thorough examination was carried out before each injection. Eagle emphasized that when thrice-weekly injections of Mapharsen were used, jaundice became the chief complication; the number of his cases $(3,376)$ was vast compared with those under review. It may be that a prolongation of the treatment to 9-12 weeks, as recorded by Eagle, would have resulted in a relatively higher incidence of complications in our cases.

TABLE 3-RESULTS OF FOLLOW-UP OF CASES UNDER REVIEW

\begin{tabular}{|c|c|c|c|c|c|c|c|c|c|}
\hline \multirow{2}{*}{$\begin{array}{l}\text { TYPE OF } \\
\text { THERAPY }\end{array}$} & \multirow{2}{*}{\multicolumn{2}{|c|}{$\underset{\text { HISTORY }}{\text { SUBSEQUENT }}$}} & \multirow{2}{*}{$\begin{array}{l}\text { NUMBER } \\
\text { OF CASES }\end{array}$} & \multicolumn{3}{|c|}{$\begin{array}{l}\text { PERIOD OF OBSERVATION } \\
\text { (in terms of months) }\end{array}$} & \multicolumn{3}{|c|}{ WASSERMANN RESULT } \\
\hline & & & & $\overline{\text { Maximum }}$ & $\overline{\text { Minimum }}$ & Average & Positiv & Negative & Doubtful \\
\hline & \multicolumn{9}{|c|}{ Seronegative Primary Syphilis } \\
\hline 20-day & $\left\{\begin{array}{l}\text { Attending } \\
\text { Defaulting } \\
\text { Transferred }\end{array}\right.$ & $\begin{array}{l}\cdots \\
\cdots\end{array}$ & $\begin{array}{l}6 \\
4 \\
9\end{array}$ & $\begin{array}{r}16 \\
5 \\
9\end{array}$ & $\frac{5}{-}$ & $\begin{array}{r}10 \cdot 3 \\
3 \cdot 1 \\
2 \cdot 5\end{array}$ & E & $\begin{array}{l}6 \\
4 \\
9\end{array}$ & Z \\
\hline 30-day & $\left\{\begin{array}{l}\text { Attending } \\
\text { Defaulting } \\
\text { Transferred }\end{array}\right.$ & $\begin{array}{l}\cdots \\
\cdots\end{array}$ & $\begin{array}{l}1 \\
1 \\
1\end{array}$ & $\begin{array}{r}4 \\
2 \\
10\end{array}$ & E & - & E & $\begin{array}{r}1 \\
1 \\
1\end{array}$ & $=$ \\
\hline 49-day & $\left\{\begin{array}{l}\text { Attending } \\
\text { Defaulting } \\
\text { Transferred }\end{array}\right.$ & $\begin{array}{l}\cdots \\
\cdots\end{array}$ & $\begin{array}{l}3 \\
3 \\
3^{*}\end{array}$ & $\begin{array}{r}5 \\
5 \\
-\end{array}$ & $\begin{array}{r}4 \\
3 \\
-\end{array}$ & $\begin{array}{l}4 \cdot 6 \\
4 \cdot 3 \\
-\end{array}$ & E & $\begin{array}{l}3 \\
3 \\
-\end{array}$ & $=$ \\
\hline & \multicolumn{9}{|c|}{ Seropositive Primary Syphilis } \\
\hline 20-day & $\left\{\begin{array}{l}\text { Attending } \\
\text { Defaulting } \\
\text { Transferred }\end{array}\right.$ & $\begin{array}{l}\ddot{ } \\
\cdots\end{array}$ & $\begin{array}{r}8 \\
4 \\
14\end{array}$ & $\begin{array}{r}13 \\
6 \\
9\end{array}$ & 二 & $\begin{array}{l}5 \cdot 1 \\
1 \cdot 7 \\
2 \cdot 1\end{array}$ & $\begin{array}{l}2 \\
1 \\
4\end{array}$ & $\begin{array}{l}3 \\
6 \\
9\end{array}$ & $\frac{-}{1}$ \\
\hline 49-day & $\left\{\begin{array}{l}\text { Attending } \\
\text { Defaulting } \\
\text { Transferred }\end{array}\right.$ & $\begin{array}{l}\ddot{ } \\
\cdots\end{array}$ & $\begin{array}{l}3 \\
1 \\
4\end{array}$ & $\begin{array}{l}6 \\
7 \\
5\end{array}$ & $\frac{4}{-}$ & $\frac{5 \cdot 3}{1 \cdot 2}$ & $\ldots$ & $\begin{array}{l}2 \\
1 \\
4\end{array}$ & E \\
\hline . & \multicolumn{9}{|c|}{ Sero-doubtful Primary Syphilis } \\
\hline 20-day & $\left\{\begin{array}{l}\text { Attending } \\
\text { Defaulting } \\
\text { Transferred }\end{array}\right.$ & $\begin{array}{l}\ddot{*} \\
\dot{*}\end{array}$ & $\begin{array}{l}-2 \\
1\end{array}$ & $\begin{array}{r}-4 \\
3\end{array}$ & 二 & $\overline{2}$ & - & $\overline{1}$ & $\frac{1}{1}$ \\
\hline \multirow[t]{2}{*}{ 49-day } & $\left\{\begin{array}{l}\text { Attending } \\
\text { Defaulting } \\
\text { Transferred }\end{array}\right.$ & $\begin{array}{l}\ldots \\
\cdots\end{array}$ & $\frac{3}{1}$ & $\frac{15}{1}$ & $\frac{3}{-}$ & $\frac{9}{-}$ & $=$ & $\frac{3}{1}$ & E. \\
\hline & \multicolumn{9}{|c|}{ Secondary Syphilis } \\
\hline 20-day & $\left\{\begin{array}{l}\text { Attending } \\
\text { Defaulting } \\
\text { Transferred }\end{array}\right.$ & $\begin{array}{l}\ddot{*} \\
\cdots\end{array}$ & $\begin{array}{r}11 \\
7 \\
6\end{array}$ & $\begin{array}{r}13 \\
2 \\
6\end{array}$ & $\stackrel{5}{-}$ & $\begin{array}{l}9.3 \\
1.8 \\
2.6\end{array}$ & $\begin{array}{r}-1 \\
1\end{array}$ & $\begin{array}{r}11 \\
4 \\
4\end{array}$ & $\frac{}{2}$ \\
\hline 30-day & $\left\{\begin{array}{l}\text { Attending } \\
\text { Defaulting } \\
\text { Transferred }\end{array}\right.$ & $\begin{array}{l}\cdots \\
\cdots\end{array}$ & $\begin{array}{l}8 \\
3 \\
4\end{array}$ & $\frac{6}{5}$ & E & $\frac{3 \cdot 1}{1 \cdot 2}$ & $\frac{-}{4}$ & $\underline{8}$ & E \\
\hline 49-day & $\left\{\begin{array}{l}\text { Attending } \\
\text { Defaulting } \\
\text { Transferred }\end{array}\right.$ & $\ddot{*}$ & $\begin{array}{l}3 \\
3+ \\
1\end{array}$ & $\frac{16}{3}$ & - & $\frac{10.5}{-}$ & E & $\frac{3}{1}$ & 二 \\
\hline
\end{tabular}

* Transferred as soon as treatment was completed.

$\uparrow$ Defaulted as

Incidence of defaulting. - The high defaulter rate from surveillance in secondary syphilis (as shown in Table 5) was common to all forms of therapy employed during 
1944 in this clinic, and many patients belonging to this category failed to appreciate the necessity for attending regularly or refused to do so. The defaulter rates shown in Table 5 are much too high, but it is likely that the figures would have been more satisfactory had the present social follow-up facilities then been available.

\section{Discussion}

In assessing the value of any new scheme of treatment for early syphilis due regard must be given to the following points.

(1) The need to eliminate contagious syphilitic lesions as quickly as possible.

(2) The reduction of the relapse rate, clinically and serologically, to a minimum, if possible to zero.

(3) The need to keep as low as possible the defaulter rate during treatment and follow-up, especially during the former.

(4) The reduction in the incidence of subsequent cardiovascular syphilis or of neurosyphilis, which incidence will be reduced by efficient antisyphilitic treatment for early syphilis and by adequate follow-up.

(5) The effective treatment of the pregnant syphilitic woman, with the dual aim of curing her and consequently of ensuring a healthy child.

Equally desirable are first, a minimal incidence of complications (and if complications must occur, ensuring that they are of a mild nature), secondly, a negligible mortality rate, and thirdly, a scheme of treatment which does not interfere with the patient's ability to earn a living. The economic factor is a very real one and should not be overlooked.

Whether or not any of the more intensive forms of therapy will fulfil these requirements remains to be seen.

TABLE 4-WASSERMANN REACTION CONVERSION RATE

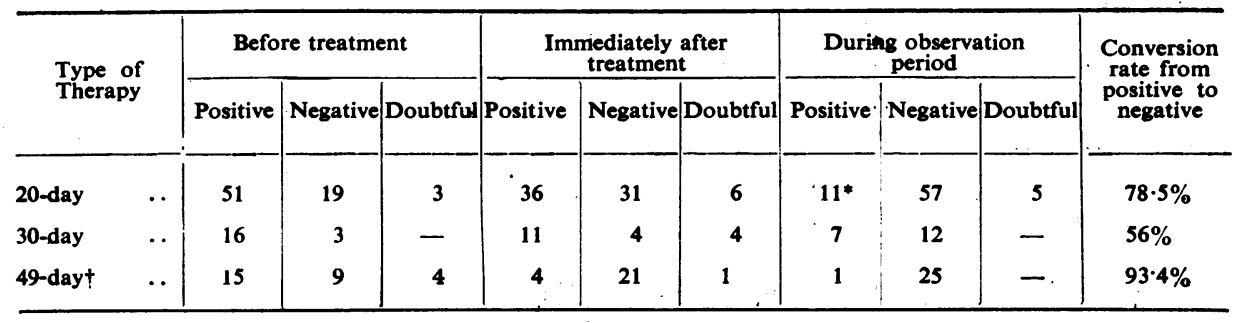

* Including 2 patients who relapsed after 5 and 3 months' interval.

$\uparrow$ Two patients defaulted during treatment.

In the series under review, $9 \cdot 1$ per cent of the cases showed complications which were relatively mild compared with those experienced in the hyper-intensive forms of treatment. Hyper-intensive methods undoubtedly have their advantages, as, for example, the fact that the venereologist can administer to the early syphilitic a large amount of arsenic in a remarkably short space of time, with the result that contagious lesions are rapidly rendered innocuous. Likewise, from an entirely different point of view, this form of therapy is to be recommended because prolonged conservative treatment-albeit in a form tried and proved to be efficient, and one which has been the bulwark of modern syphilitic therapy-subjects the social department of a venereal diseases centre to a heavy strain, since defaulter rates are liable to increase at a rate directly proportional to the duration of treatment. It must be remembered that the patient of the type which is prone to default belongs to that social stratum which supplies a venereal diseases clinic with the bulk of its patients; therefore the preceding remarks with reference to intensifying arsenical administration are applicable to the majority of its cases of syphilis.

Offsetting the apparent advantages of hyper-intensive therapy is the large incidence of serious complications with an associated higher mortality rate. 
The relapse rate experienced by Cannon and his co-workers, together with the serious nature of the complications, led them to discontinue this form of treatment. Bundesen, Bauer and Kendell likewise experienced such severe reactions with hyper-intensive shortterm therapy (Mapharsen administration twice daily for 10 days) that they were forced to discontinue this line of treatment ; they obtained much better results by administering Mapharsen thrice weekly, together with bismuth twice weekly, for 8 weeks. It would appear that the mortality rate was in the region of $1: 200-250$, as compared with the intensive and more conservative methods with their mortality rates of $1: 1,500$ and $1: 2,500$ respectively. A further drawback to the hyper-intensive method is the necessity for in-patient treatment. Stokes quotes a first-class clinic as being able to hold 50 per cent of early syphilitic cases until cured, and says that 70-80 per cent of the patients may receive satisfactory regular treatment.

In the prolonged type of treatment the defaulter problem is a very real one, with its associated dissemination of disease, together with allied increased morbidity and mortality rates directly or indirectly attributable to syphilis. . With reference to the defaulter rate, our experience agrees with that of Shaffer and Salchow and of Cole, Heisel and Stroud, in that it is too high in the 7-10 weeks' course. Cole, Heisel and Stroud's series showed a defaulter rate of 16.2 per cent, as compared with ours of 25 per cent.

TABLE 5-INCIDENCE OF DEFAULT IN 119 CASES*

\begin{tabular}{|c|c|c|c|c|c|c|c|c|}
\hline \multicolumn{5}{|c|}{ Serological type of syphilis } & \multirow{2}{*}{$\begin{array}{c}\text { Total cases } \\
31\end{array}$} & \multirow{2}{*}{$\frac{\text { Still attending }}{10}$} & \multirow{2}{*}{$\begin{array}{c}\text { Defaulters } \\
8\end{array}$} & \multirow{2}{*}{ Transferred } \\
\hline Seronegative & .. & .. & .. & .. & & & & \\
\hline Seropositive & .. & .. & .. & .. & 35 & 11 & 5 & 19 \\
\hline Sero-doubtful & .. & .. & .. & .. & 7 & 3 & 2 & 2 \\
\hline Secondary .. & . & .. & .. & .. & 46 & 22 & 13 & 11 \\
\hline \multicolumn{9}{|c|}{ Type of treatment received } \\
\hline 20-day & .. & .. & $\therefore$ & .. & 72 & 25 & 17 & 30 \\
\hline 30-day & .. & .. & .. & $\cdots$ & 19 & 9 & 4 & 6 \\
\hline 49-day & .. & .. & . & .. & 28 & 12 & 7 & 9 \\
\hline
\end{tabular}

* This table does not include one case of latent syphilis.

In planning the treatment of early syphilis, importance should be attached to the development of natural partial immunity, which should be encouraged at all times. As to whether the relatively intensive arsenical treatment suppresses this development, no one can be dogmatic, but the administration of bismuth should in part assist in the promotion of natural partial immunity by stimulating the resistance of tissues. No case has been treated with arsenic alone since bismuth was recognized as being not only a desirable, but an essential adjuvant to arsenic in the treatment of early syphilis. Hood and Eagle both found that in the more intensive forms of therapy the relapse rate was decidedly lower when bismuth was employed.

The basis of modern intensive therapy in all forms, as compared with the more conservative treatment, would appear to rest on animal experimental work carried out by Eagle and Hogan, who found that the curative dose of Mapharsen in any one type of treatment was partly independent of the time period over which treatment was given. In view of the unfavourable aspects of hyper-intensive therapy, this statement would appear to be more applicable to the less intensive methods, but which is the best of the three methods employed in this series, it is difficult to say. For example, compared with the 20-day and 30-day courses, the 49-day course showed the highest defaulter rate, also the highest incidence of complications which were of a more serious nature. On the other hand, the 49-day course showed the highest Wassermann reaction conversion rate from 


\section{INTENSIVE ARSENOTHERAPY IN EARLY SYPHILIS}

positivity to negativity. Apart from the low conversion rate, the 30-day course would appear to have given the most satisfactory results, but the number of cases in this category amounts only to 16 per cent of the total number of cases reviewed.

Conclusions arrived at must be merely tentative because the number of cases is limited, and at least two years, preferably five, must elapse before a true evaluation can be made. Since the maximal period of observation to date is only 16 months, clinical and serological relapses are within the bounds of possibility. An ultimate assessment may show that none of the three methods has any advantage over the other two from the defaulter and relapse rate standpoints. Furthermore, the advantages of penicillin, which is the most recent acquisition to our therapeutic armamentarium against syphilis, may well nullify or modify any contemplated plan of therapy in which the curative dose of arsenoxide preparation is administered over a period of a few days or weeks at the most.

\section{Summary}

A preliminary report is submitted on the treatment of 120 cases of early syphilis by intensive and semi-intensive methods. Methods are labelled intensive when the patient receives 20 or 30 consecutive daily injections of an arsenoxide preparation, plus bismuth twice weekly, whereas the term semi-intensive implies the thriceweekly administration of an arsenoxide preparation, concurrently with bismuth twice weekly, for 7 weeks. Hyper-intensive methods were not employed for the reasons mentioned above.

The results of intensive methods of arsenic administration indicated the ability of the majority of patients to tolerate the estimated curative dose given within a relatively limited period of time. The average percentage of complications was $9 \cdot 1$, of which only $2 \cdot 5$ could be classified as severe. The mortality rate was nil.

The follow-up defaulter rate was too high in all three types of treatment.

One case has shown serological and another clinical and serological relapse after 3 and 5 months negativity, respectively. The few cerebrospinal examinations carried out showed no abnormalities.

The advantages and disadvantages of all three methods of treatment are discussed, and no claim is made for any one scheme of therapy as being superior to the others. Evaluation of any scheme of antisyphilitic therapy necessitates a prolonged period of subsequent surveillance, and since the maximal period in this experiment is restricted to 16 months, all observations are accordingly subject to qualification.

\section{BIBLIOGRAPHY AND REFERENCES}

Bundesen, H. N., Bauer, T. J., and Kendell, H. W. (1943) J. Amer. med. Ass., 123, 816. Cannon, A. B., Fisher, J. K., Rodriguez, J., Beattie, Guila F., and Maechling, Eugenia (1944) J. Amer. med. Ass., 126, 544.

Cole, H. N., Heisel, E. B., and Stroud, G. (1943) J. Amer. med. Ass., 123, 253.

Co-operating Clinics of New York and Midwestern Groups (1944) J. Amer. med. Ass., 126, 554.

Eagle, H. (1944) J. Amer. med. Ass., 126, 538.

and Hogan, R. B. (1943) J. vener. Dis. Inform., 24, 33, 69, 159.

Goldblatt, S. (1944) Arch. Derm. Syph., 49, 403.

Hood, B. J. (1943) Amer. J. Syph., 27, 267.

Jones, N., Carpenter, C. M., Boak, Ruth A., Warren, S. L., and Hanson, H. (1944) J. vener. Dis. Inform., 25, 99.

Schoch, A. G., and Alexander, L. J. (1941) ${ }^{1}$ Amer. J. Syph., 25, 607.

(1942)2 Arch. Derm. Syph., 46, 128.

Shaffer, L. W., and Salchow, P. T. (1942) Report of Social Hygiene Division, Detroit Department of Health.

Stokes, J. H. (1942) J. Amer. med. Ass., 120, 1093.

Thomas, E. W., and Wexler, Gertrude (1944) J. Amer. med. Ass., 126, 550. 